\title{
Milk production potential of South African Boer and Nguni goats
}

\author{
V.M.Mmbengwa ${ }^{1 \#}$, L.M.Schwalbach ${ }^{2}$, J.P.C.Greyling ${ }^{2}$, and M.D. Fair ${ }^{2}$ \\ ${ }^{1}$ Dept of Animal Production, University of the North, P/Bag X1106, Sovenga, 0727 \\ ${ }^{2}$ Dept of Animal Science, University of the Free State, PO Box 339, Bloemfortein, 9300 \\ \# e-mail:MmbengwaV@unin.unorth.ac.za
}

\section{Introduction}

Given the ever-growing human population, particularly in the rural areas of South Africa, the concurrent demand for animal protein is ever increasing. In these over-populated rural areas, the shortage of adequate grazing and the relatively high maintenance costs of cattle, make goat farming an alternative proposition for meat and milk production. Goats are hardy, less labor intensive and have less maintenance nutritional requirements than cattle (Devendra, 1978; NRC, 1981), which makes them a better option for small-scale farming under the harsh nutritional conditions observed in most of these rural areas (Donkin et al., 1996). Furthermore it has been indicated that most of these small-scale farmers do not have the financial means to acquire traditional dairy goat animals (for milk production). These exotic breeds (Saanen and Toggenburg) are more expensive and more susceptible to local diseases and parasites, compared to the local indigenous, adapted and more affordable breeds (Boer Goat-BG and Nguni Goat/Kwazulu Natal Goats-NG). The primary aim of this trial was to investigate the milk production potential (quantity and quality) of indigenous goats (BG and $\mathrm{NG}$ ) under intensive and extensive nutritional regimes.

\section{Materials and Methods}

A Latin Square experimental design (two breeds and two nutritional management systems) was used in this trial. Thirty-six recently kidded indigenous does (18 BG and $18 \mathrm{NG}$ ) were used in this trial. Half ( $\mathrm{n}=9)$ of the BG and half ( $n=9)$ of the NG were randomly allocated to extensive (veld) and intensive (high energy concentrate) feeding groups, respectively. Milk production was determined by hand milking after the administration of an intramuscular injection of oxytocin (10 i.u.), twice a day within two hours, two times a week between day 7 and day 100 post-kidding. The first milking was to empty the udder (no records taken) and the second milking done two hours after the first milking. The total daily milk production per doe ( 24 hours) was extrapolated by the milk production recorded in this second milking (Du Toit, 1980). Milk samples were collected for milk composition analysis, twice a week. The percentage protein, non-fat solids (SNF) and lactose in the samples were determined. The mean milk yield (quantity and quality), breed, nutritional management and the interaction between the breed and the nutritional management constituted variables analysed. Data was analysed using one way ANOVA (SAS, 1991).

\section{Results and Discussion}

The average daily milk production and milk composition of both breeds are reflected in Table 1

Table 1 Goat milk production and composition (7-100 days) for Boer and Nguni does.

\begin{tabular}{|c|c|c|c|c|c|c|c|}
\hline \multirow{2}{*}{$\begin{array}{l}\text { Nutritional } \\
\text { Management } \\
\text { Breed }\end{array}$} & \multicolumn{2}{|c|}{ Intensive feeding } & \multicolumn{2}{|c|}{ Extensive feeding } & \multicolumn{3}{|c|}{ Differences } \\
\hline & BG & Nguni & BG & Nguni & M & B & Int \\
\hline MiIk production (l) & $3.12 \pm 1.48$ & $1.42 \pm 1.37$ & $0.78 \pm 0.67$ & $0.65 \pm 0.64$ & $*$ & ns & ns \\
\hline Fat $(\%)$ & $6.13 \pm 2.23$ & $7.48 \pm 3.23$ & $6.39 \pm 2.08$ & $6.04 \pm 2.06$ & ns & $*$ & $*$ \\
\hline Protein $(\%)$ & $4.97 \pm 0.97$ & $4.95 \pm 1.95$ & $5.03 \pm 2.96$ & $4.54 \pm 2.79$ & $*$ & ns & $*$ \\
\hline Lactose $(\%)$ & $4.97 \pm 0.68$ & $4.27 \pm 0.97$ & $4.48 \pm 0.59$ & $4.50 \pm 0.35$ & $*$ & ns & $*$ \\
\hline $\operatorname{SNF}(\%)$ & $10.42 \pm 6.47$ & $9.88 \pm 1.53$ & $10.68 \pm 5.13$ & $9.55 \pm 1.91$ & $*$ & $*$ & $*$ \\
\hline
\end{tabular}

M- Nutritional management, B- Breed and Int- Interaction (Nutrition and breed); 1 = Litres; ns = Not significant $* \mathrm{P}<0.05$

From the data it is evident that the mean daily milk yield of the Nguni does is very low regardless of the feeding regime. These observations are in agreement with those of other reports on indigenous goats in the tropics (Akinsoyinu et al., 1977). In the Jamnapari, Beetal and Barbari breeds in India, Lall \& Singh (1949) found these breeds to produced $0.75,1.0$ and $0.6 \mathrm{~kg} / \mathrm{milk} /$ day respectively, which in agreement with the findings of this trial, 


\section{Short paper and poster abstracts: $38^{\text {th }}$ Congress of the South African Society of Animal Science}

i.e.1.42 \pm 1.37 and $0.65 \pm 0.64 \mathrm{l} /$ day for $\mathrm{BG}$ and NG breeds respectively. The main reason being that most of the indigenous goats in the tropics are meat or dual purpose breeds and have not been selected for milk production. However, under high energy feeding conditions, these does and particularly the BG does produced significantly $(\mathrm{p}<0.05)$ more milk/day, compared to those under extensive or natural feeding conditions. These observations are in agreement with those of Sachedeva et al. (1974), who stated that milk production is largely influenced by the pre- and postpartum nutritional status of the does. Furthermore, Morand-Fehr \& Sauvant, (1978), found the level of dry matter and energy intake to be positively related to milk production and that any improvement in the nutritional management, particularly in the quality of the forage of the ration to increase milk yield. Mavrogenis \& Narjisse (1992) reported that better nutrition promoted higher milk yields in both local and exotic breeds. The mean fat and protein percentages observed in this trial were higher than the values reported by Ehoche \& Buvanendran (1983). There was evidence of a significant interaction between the breed and feed $(\mathrm{P}<0.01)$ on both fat and protein content in milk, which limits discussion on these parameters. The relationship between milk yield, fat and protein percentages in the milk follow the same trend as that observed in cow milk (Ehoche \& Buvanendran, 1983). The correlation between milk yield and fat (\%) is negative, whilst the correlation between protein and fat is moderately high and positive. The mean percentages of SNF and lactose were much lower than those presented by Akinsoyinu et al. (1977), however higher than the mean values for fat and protein observed in this trial-when compared to those reported by Ling et al. (1961).

\section{Conclusions}

Although the daily milk yield was relatively low in the two goat breeds, milk produced was of a higher quality, when compared to that of dairy goat breeds. Under more intensive feeding management, with a well balanced diet, milk production can be considerably improved. Given the abundance and adaptability of these breeds to the harsh condition in South African rural communities, these breeds can be utilized to alleviate malnutrition in these areas, pending the supply of a well balanced diet and also serve as a possible source of income.

\section{References}

Akinosiyinu, A.O. et al., 1977. J.Dairy Res.44, 57.

Du Toit, J.E.J., 1980. PhD Thesis, UOVS, Bloemfontein.

Devendra, C., 1978. Anim. Prod. 14, 19.

Donkin, E.F. et al., 1996. VI International Conference on Goats, Vol. 1. Beijing, China. pp132.

Ehoche O.W.,1983. Anim.Prod. 19, 19.

Lall, H.K. \& Singh, J.,1946. Ind.J.of Vet.Sci. 19, 261.

Ling, E.R. et al., 1961. Milk: the mammary gland and its secretion. Academic Press, NewYork. Pp 2195.

Mavrogenis, A.P. \& Narjisse, H., 1992. V International Conference on Goats Vol 2. Dehli, India. pp 31.

Morand-Fehr \& Sauvant, 1978. Liv. Prod. Sci.. 5, 203.

NRC, 1981.Nutritional Requirements for goats. National Academy Press ,Washington D.C. pp 91.

Sachdeva, K.K. et al., 1974. Milchwissenschaft. 8, 471.

SAS, 1991. SAS/STATS User guide . Release 6.0 Edition. SAS Inc. Cary, NC. 